\title{
COMPUTER SIMULATION OF STRUCTURAL VIBRATION DAMPING WITH ALLOWANCE FOR NONLOCAL PROPERTIES
}

\author{
Vladimir N. Sidorov ${ }^{1,2,3,4}$, Elena S. Badina ${ }^{1}$ \\ ${ }^{1}$ Russian University of Transport (MIIT), Moscow, RUSSIA \\ ${ }^{2}$ National Research Moscow State University of Civil Engineering, Moscow, RUSSIA \\ ${ }^{3}$ Perm National Research Polytechnic University, Perm, RUSSIA \\ ${ }^{4}$ Moscow Institute of Architecture, Moscow, RUSSIA
}

\begin{abstract}
Different approaches to the computer simulation of damping properties of structural elements, which are made of materials with complicated physical structure, such as composites and nano-materials, are considered in this paper. In such cases application of classical models, e.g. ones based on the Kelvin-Voight hypothesis, can lead to the results that are not even close to the real composite structure behavior. The main point of the proposed approaches is delocalization of the damping effects in space and time. The described nonlocal damping models are more flexible in comparison to classic ones. The model calibration based on the experiment data allows to determine the optimum value of the characteristic parameter of nonlocal model using the least square method. The results of three-dimensional numerical simulation of the composite beam vibration were used for model calibration. The numerical simulation was implemented in SIMULIA Abaqus software. The material was considered as orthotropic; its parameters were picked up according to the physical properties of the real composite material. The developed beam vibration models considering nonlocal damping were created in MATLAB. The obtained results were compared to the results based on classic Kelvin-Voight damping model.
\end{abstract}

Keywords: structural vibration, nonlocal damping, numerical simulation, flexible model

\section{ЧИСЛЕННОЕ МОДЕЛИРОВАНИЕ ГАШЕНИЯ КОЛЕБАНИЙ СТРОИТЕЛЬНЫХ КОНСТРУКЦИЙ С УЧЁТОМ НЕЛОКАЛЬНОСТИ ИХ ДЕМПФИРУЮЩИХ СВОЙСТВ}

\author{
B.Н. Сидоров ${ }^{1,2,3,4}$, E.С. Бадьина ${ }^{1}$ \\ ${ }^{1}$ Российский университет транспорта (МИИТ), г. Москва, РОССИЯ \\ ${ }^{2}$ Национальный исследовательский Московский государственный строительный университет, г. Москва, РОССИЯ \\ ${ }^{3}$ Пермский национальный исследовательский политехнический университет, г. Пермь, РОССИЯ \\ ${ }^{4}$ Московский архитектурный институт, г. Москва, РОССИЯ
}

\begin{abstract}
Аннотация: Рассматриваются подходы к численному моделированию демпфирующих параметров конструкций, выполненных из материалов со сложной физической структурой, таких как композитные и нано-материалы. Использование в этом случае классических моделей демпфирования, к примеру, основанных на гипотезе вязкого трения Фойгта, приводит к результатам расчёта, весьма далеким от реального поведения конструкций из подобных материалов. Предлагаемые в статье подходы заключаются в делокализации эффекта демпфирования, как по пространственной координате, так и во времени. Описываемые нелокальные модели демпфирования являются управляемыми. Калибровка моделей по результатам эксперимента заключается в выявлении оптимального значения управляемого параметра модели с использованием метода наименьших квадратов. В качестве опорных результатов в статье использованы данные вычислительного эксперимента над трёхмерной моделью стержневого элемента, выполненного из композитного материала. Этот численный эксперимент проведен с использованием программного комплекса SIMULIA Abaqus. Материал при этом представлен ортотропным, параметры ортотропии назначались в соответствии с физическими характеристиками рассматриваемого композитного материала. Разработанные вычислительные модели колебаний стержневого элемента с учётом нелокальности демпфирования были реализованы в программном комплексе MATLAB. Приведено сравнение полученных результатов с результатами расчётов, полученных с использованием классической модели демпфирования, основанной на гипотезе Фойгта.
\end{abstract}

Ключевые слова: колебания конструкций, нелокальное демпфирование, вычислительный эксперимент, управляемая модель 


\section{INTRODUCTION}

The materials with complicated physical structure, such as composite materials and nano-materials, become more and more widespread in the engineering practice. Generally, for the design of structures, made of such materials, the detailed three-dimensional finite element models are used. In such models materials generally are modeled as orthotropic and anisotropic ones. Problem of damping modeling for the structural composite elements is especially sophisticated. Meanwhile, the detailed three-dimensional modeling of, for example, beam elements is very often cumbrous and unreasonable. In this case, one-dimensional models, which are flexible enough for damping simulation for the composite structures, are preferable. Nonlocal damping model can be used as such flexible model.

\section{VIBRATION SIMULATION USING NONLOCAL IN SPACE DAMPING MODEL}

Damping in the certain point of the structure with longitudinal coordinate $x 1$ is assumed to be dependent not only on local value of motion velocity at this point $v(x 1)$, but also on the values of motion velocity in the neighboring points. The more distance between the two points the lower influence that one of them has on the other [2].

The Kelvin-Voigt material model is commonly used to describe the damping process in engineering structures:

$$
\sigma=E \varepsilon+\gamma E \dot{\varepsilon},
$$

where $\sigma, \varepsilon-$ normal stress and axial strain, $\dot{\varepsilon}-$ strain rate, $E$ - Young modulus, $\gamma$ - damping ratio. If we consider damping nonlocal in space, then equation (1) transforms to [2]:

$$
\sigma(x, t)=E\left[\varepsilon(x, t)+\gamma \int_{0}^{l} C_{v}(|x-\theta|) \dot{\varepsilon}(\theta, t) d \theta\right] .
$$

Here $C_{v}(|x-\theta|)$ - the kernel function of internal damping, $|x-\theta|$ - distance between the neighboring points. The $C_{v}(|x-\theta|)$ function must satisfy to normalization requirement:

$$
\int_{-\infty}^{\infty} C_{v}(|x-\theta|) d \theta=1 .
$$

In the paper the error kernel function is used:

$$
C_{v}(|x-\theta|)=\frac{\mu}{\sqrt{2 \pi}} \cdot e^{\frac{-\mu^{2}(x-\theta)^{2}}{2}} .
$$

Here $\mu$ is the parameter that characterizes the space nonlocality level in the damping model (fig. 1). The higher is $\mu$, the closer is the damping model to the classic local one (1).

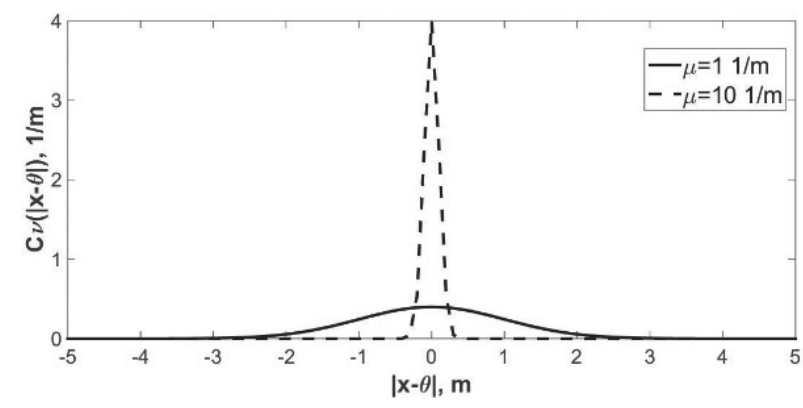

Figure 1. Error kernel functions for different influence distance parameter

The equilibrium equation for the Euler-Bernoulli beam is:

$$
\frac{\partial^{2} M(x, t)}{\partial x^{2}}=m \frac{\partial^{2} v(x, t)}{\partial t^{2}}-q(x, t) .
$$

Here $v(x, t)$ is beam deflection, $m$ is the distributed mass, $q(x, t)$ - distributed load.

Considering (2) and the plane sections assumption, the bending moment expression for the nonlocal approach is:

$$
\begin{aligned}
& M(x, t)=-E I\left[\frac{\partial^{2} w(x, t)}{\partial x^{2}}\right. \\
& \left.+\gamma \int_{0}^{l} C_{v}(|x-\theta|) \frac{\partial^{3} w(\theta, t)}{\partial \theta^{2} \partial t} d \theta\right]
\end{aligned}
$$

where $E I$ - the bending stiffness of the beam. Substituting the second derivative of the bending moment expression (6) to the left part of the equation (5), we obtain the vibrating beam 
equilibrium equation regarding the deflection function $v(x, t)$ :

$$
\begin{aligned}
& \frac{\partial^{2} v(x, t)}{\partial t^{2}}+\frac{E I}{m}\left[\frac{\partial^{4} v(x, t)}{\partial x^{4}}+\right. \\
& \left.+\gamma \frac{\partial^{2}}{\partial x^{2}} \int_{0}^{l} \mathrm{C}_{\mathrm{v}}(|\mathrm{x}-\theta|) \frac{\partial^{3} v(\theta, t)}{\partial \theta^{2} \partial t} d \theta\right]=\frac{q(x, t)}{m} .
\end{aligned}
$$

To solve the equation (7) Galerkin method was used, with the first beam Eigen forms, responding to the boundary conditions, considered as the coordinate functions. The satisfying number of the coordinate functions was picked up based on the numerical study of the results convergence.

Consider GFRP beam with the fixed ends made of orthotropic thermoset vinyl ester class 1 FRP under instantly applied distributed load $q=10 \mathrm{kN} / \mathrm{m}$. The beam is $6 \mathrm{~m}$ long and has a rectangular cross-section. The characteristics of the material obtained experimentally in [9, $10,11]$.

The method of determining the influence distance $\mu$ using the least squares based on the numerical simulation data is described in [6]. This method was also used in this paper. For the nonlocal in space damping model calibration the three-dimensional finite element model of the beam was constructed in SIMULIA Abaqus CAE (fig .2).

The material is suggested to be orthotropic. The calibrated value of the influence distance is $\mu=$ 1.071/ $m$ Comparison between the results of onedimensional modelling of the beam vibrations considering nonlocal in space damping with

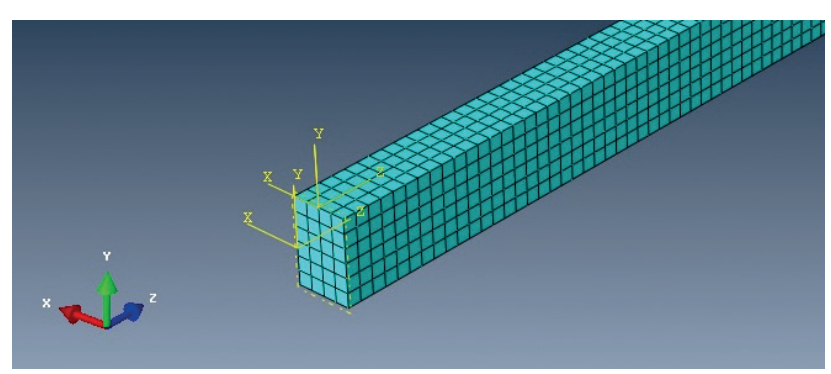

Figure 2. Finite element model of the considering beam in SIMULIA Abaqus CAE the calibrated $\mu$ and the results of detailed threedimensional finite element simulation is shown on the fig. 3 .

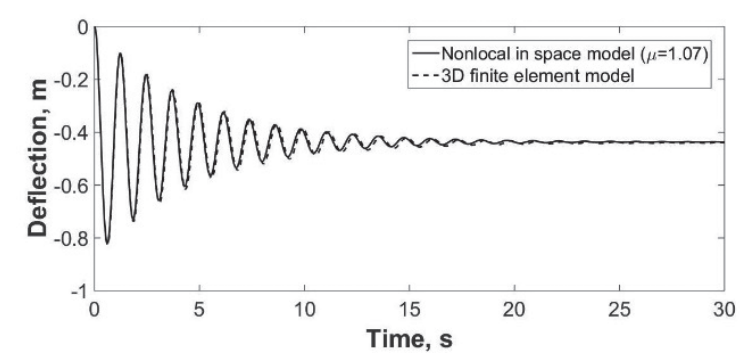

Figure 3. Comparison of the results obtained using nonlocal in space damping model and ones obtained in Abaqus CAE

The difference between Abaqus results obtained with 3D orthotropic material model and the results obtained with one-dimensional beam where local Kelvin-Voigt model is used to describe damping is shown on fig. 4.

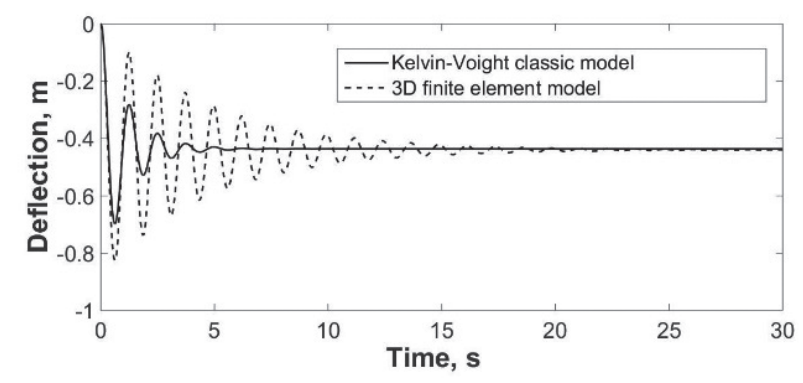

Figure 4. Deflection of the beam using local Kelvin-Voigt damping model in comparison to $3 D$ numerical simulation data

\section{VIBRATION SIMULATION USING NONLOCAL IN TIME DAMPING MODEL}

The beam element vibration process considering damping that is nonlocal in time is modeled using the finite element analysis. Using this method, the equilibrium equation of the beam bending in time is solved. In FEA the equilibrium equation is applied in matrix form: 


$$
M \cdot \ddot{\bar{V}}(t)+D \cdot \dot{\bar{V}}(t)+K \cdot \bar{V}(t)=\bar{F}(t)
$$

Here $\dot{V}(t)$ - vector of displacements of the finite element model nodes (dot indicates time derivative), $K$ - stiffness matrix of the finite element model, $D$ - damping matrix, $M$ - mass matrix, $F(t)$ - vector external forces that are acting at the considered point of the structure.

To simulate the nonlocal in time properties of structural vibration damping («damping with memory») equation (8) is represented as:

$$
\begin{aligned}
& M \cdot \ddot{\bar{V}}(t)+D \cdot \int_{0}^{t} G(t-\tau) \cdot \dot{\bar{V}}(\tau) d \tau+ \\
& K \cdot \bar{V}(t)=\bar{F}(t) .
\end{aligned}
$$

Here $G(t-\tau)$ is the kernel function for nonlocal in time damping. This function describes the decrease of the strain rate influence at the moment $\tau$ on the damping at the current moment $t$, and:

$$
\int_{0}^{t} G(t-\tau) d \tau=1
$$

As above, the error function is taken here for error function, constructed on the base of Gauss integral:

$$
\int_{-\infty}^{\infty} e^{-x^{2}} d x=\sqrt{\pi},
$$

that, taking into account the condition (10), can be written as:

$$
G(t-\tau)=\frac{2 \mu}{\sqrt{\pi}} \cdot e^{-\mu^{2}(t-\tau)^{2}},
$$

Here $\mu$ is a parameter, that characterize the level of damping nonlocality in time.

To solve the dynamic equilibrium equation, the method of the central differences is used [8]. In this case, the first and second order time derivatives of the displacement vector $V(t)$ participating in (8) and (9) are approximated by central finite differences. Then the equation (8), obviously, takes the following form:

$$
\begin{aligned}
& \frac{1}{\Delta t^{2}} \cdot M \cdot\left(\bar{V}_{i+1}-2 \bar{V}_{i}+\bar{V}_{i-1}\right)+\frac{1}{2 \cdot \Delta t} \cdot D \\
& \cdot\left(\bar{V}_{i+1}-\bar{V}_{i-1}\right)+K \cdot \bar{V}(t)=\bar{F}_{i} .
\end{aligned}
$$

Here $i=1,2,3, \ldots \quad$ - number of the considered moment in time $t, \Delta t$ - time increment.

In order to replace the classical damping model in (13) with the damping model with memory, at first we represent the central difference in the second term on the left-hand side of equation (13), which is responsible for damping, as the average of the «forward» and «backward» differences:

$$
\begin{gathered}
\frac{1}{\Delta t^{2}} \cdot M \cdot\left(\bar{V}_{i+1}-2 \bar{V}_{i}+\bar{V}_{i-1}\right)+\frac{1}{2 \cdot \Delta t} \cdot D \\
\cdot\left(\bar{V}_{i}-\bar{V}_{i-1}\right)+ \\
\frac{1}{2 \cdot \Delta t} \cdot D \cdot\left(\bar{V}_{i+1}-\bar{V}_{i}\right)+K \cdot \bar{V}(t)=\bar{F}_{i} .
\end{gathered}
$$

The term with the «backward» difference is replaced by:

$$
\begin{aligned}
& \frac{1}{2 \cdot \Delta t} \cdot D \cdot\left(\bar{V}_{i}-\bar{V}_{i-1}\right) \\
& =\frac{D}{2} \sum_{i=1}^{i} \bar{G}(i, j)\left(\bar{V}_{j}-\bar{V}_{j-1}\right),
\end{aligned}
$$

where $i$ - number of the time step which is corresponding to the considered time moment $\mathrm{t}$, $t=\Delta t \cdot i, \tau=\Delta t \cdot j, j=1,2, \ldots, i-$ number of the time step when calculating the kernel $G(i, j)$.

$G^{\prime}(i, j)$ is the discrete analogue of $G(t-\tau)$ kernel (12), which for the error function (12) is calculated as follows:

$$
\bar{G}(i, j)=\frac{2 \mu}{\sqrt{\pi}} \cdot e^{-\mu^{2}\left(t-\left(\tau-\frac{\Delta t}{2}\right)\right)^{2}} .
$$

After the described transformations equation (14) can be written as:

$$
\begin{aligned}
& \frac{1}{\Delta t^{2}} \cdot M \cdot\left(\bar{V}_{i+1}-2 \bar{V}_{i}+\bar{V}_{i-1}\right)+\frac{D}{2} \cdot \bar{Z}+ \\
& \frac{1}{2 \cdot \Delta t} \cdot D \cdot\left(\bar{V}_{i+1}-\bar{V}_{i}\right)+K \cdot \bar{V}(t)=\bar{F}_{i}
\end{aligned}
$$

where

$$
\bar{Z}=\frac{2 \mu}{\sqrt{\pi}} \cdot e^{-\mu^{2}\left(t-\left(\tau-\frac{\Delta t}{2}\right)\right)^{2}}\left(\bar{V}_{i}-\bar{V}_{i-1}\right) .
$$

Still, the influence distance $\mu$ determine the nonlocality level in structure. The higher is $\mu$, the closer is the damping model to the classic one.

Transform (17) to the computational scheme for the step-by-step calculating of $V_{i+1}$ using the vectors $\dot{V}_{i}$ and $\dot{V}_{i-1}$, which are calculated on the increments $i$ and $i-1$ :

$$
\bar{V}_{i+1}=Q \cdot \bar{F}_{i}-Q_{1} \cdot \bar{V}_{i}-Q_{2} \cdot \bar{V}_{i-1}-Q_{3} \cdot \bar{Z}
$$


where:

$$
\begin{gathered}
Q=\left(\frac{1}{\Delta t^{2}} M+\frac{1}{2 \cdot \Delta t} D\right)^{-1}, \\
Q_{1}=Q \cdot\left(-\frac{2}{\Delta t^{2}} M-\frac{1}{2 \cdot \Delta t} D+K\right), \\
Q_{2}=\frac{1}{\Delta t^{2}} Q \cdot M, \\
Q_{3}=\frac{1}{2} Q \cdot D .
\end{gathered}
$$

For the first step $i=1$ we assume $\dot{V}_{0}=0$ and $\dot{V}_{1}=0$ as the initial conditions.

The calibration of the nonlocal in time damping model was implemented, as above, based on the results of the numerical simulation of threedimensional finite element beam vibration in SIMULIAAbaqus CAE. The determined optimum value of $\mu$ for the beam, that was considered in privious section, is $\mu=0.11 / s$. The displacements of middle section of the beam in time are shown in fig. 5. The solid line shows the displacements of the beam which is obtained using a calibrated nonlocal model, and the dashed curve - using a 3D model built in SIMULIA Abaqus.

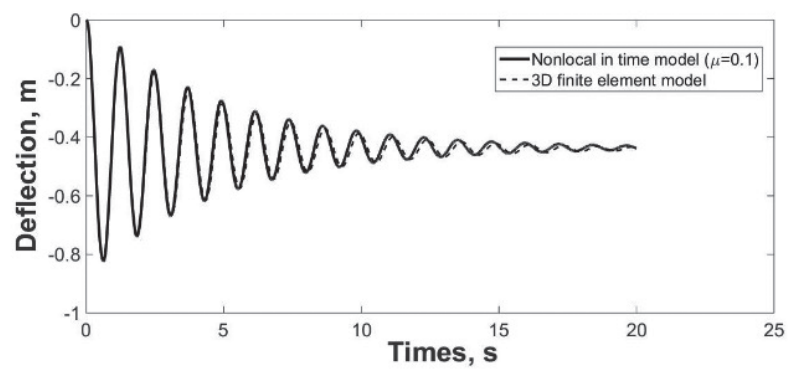

Figure 5. Deflection of the beam obtained with calibrated nonlocal in time damping model in comparison to $3 D$ numerical simulation data

It is obvious, that calibrated nonlocal model allows to obtain much more accurate results, than the Kelvin-Voight classic model (fig. 4).

\section{CONCLUSION}

In comparison to local time models the model presented in this article allows managing the main characteristics of the simulated composite structures vibration process in more reliable and flexible way. Increased flexibility makes it possible to use onedimensional models of beam elements in the dynamic analysis of structures which are made of modern composite materials with orthotropic properties.

\section{REFERENCES}

1. Banks H.T. and Inman D.J. 1991 On damping Mechanisms in Beams Journal of Applied Mechanics, 58(3). - pp. 716-723.

2. Lei Y., Friswell M.I. and Adhikari S. 2006 A Galerkin Method for Distributed Systems with Non-local Damping Int.Journal of Solids and Structures 43. - p. 3381-3400.

3. Rossikhin Yu.A. and Shitikova M.V. 2010 Application of Fractional Calculus for Dynamic Problems of Solid Mechanics: Novel Trends and Recent Results Applied Mechanics Reviews 63010801 p. 1-52.

4. Potapov V.D. 2012 Problems of Machinery and Reliability p. 25-31.

5. Fyodorov V.S., Sidorov V.N. and Shepitko E.S. 2018 Nonlocal damping consideration for the computer modelling of linear and nonlinear systems vibrations under the stochastic loads IOP Conf. Series: Materials Science and Engineering 456012040

6. E.S. Shepitko and V.N. Sidorov. Defining of nonlocal damping model parameters based on composite beam dynamic behaviour numerical simulation results // IOP Conf. Series: Materials Science and Engineering 675 (2019) 012056

7. Akimov P.A., Belostosky A.M., Kaytukov T.B., Mozgaleva M.A. and Aslami M. 2018 About Several Numerical and Semianalytical Methods of Local Structural Analysis Int. Journal for Computational Civil and Structural Engineering 14 i 4 p. 59-69.

8. Bathe K.-J., Wilson E.L. Chislennye metody analiza i metod konechnyh jelementov [Numerical methods in finite element analysis]. Moscow, Stroyizdat, 1982 (in Russian).

9. Landherr J.C. Dynamic analysis of a FRP deployable box beam. Master of Applied Science Thesis. Kingston: Queen's University, 2008. 
10. Lim R.A. 2016 Structural monitoring of a $10 \mathrm{~m}$ fibre reinforced polymer bridge subjected to severe damage (Kingston: Queen's University)

11. Xie A. Development of an FRP Deployable Bridge, Master of Applied Science Thesis, Department of Civil Engineering, Royal Military College of Canada, 2007.

\section{СПИСОК ЛИТЕРАТУРЫ}

1. Banks H.T. and Inman D.J. 1991 On damping Mechanisms in Beams Journal of Applied Mechanics, 58(3). - pp. 716-723.

2. Lei Y., Friswell M.I. and Adhikari S. 2006 A Galerkin Method for Distributed Systems with Non-local Damping Int.Journal of Solids and Structures 43. - p. 3381-3400.

3. Rossikhin Yu.A. and Shitikova M.V. 2010 Application of Fractional Calculus for Dynamic Problems of Solid Mechanics: Novel Trends and Recent Results Applied Mechanics Reviews 63010801 p. 1-52.

4. Potapov V.D. 2012 Problems of Machinery and Reliability p. 25-31.

5. Fyodorov V.S., Sidorov V.N. and Shepitko E.S. 2018 Nonlocal damping consideration for the computer modelling of linear and nonlinear systems vibrations under the stochastic loads IOP Conf. Series: Materials Science and Engineering 456012040

6. E.S. Shepitko and V.N. Sidorov. Defining of nonlocal damping model parameters based on composite beam dynamic behaviour numerical simulation results // IOP Conf. Series: Materials Science and Engineering 675 (2019) 012056

7. Akimov P.A., Belostosky A.M., Kaytukov T.B., Mozgaleva M.A. and Aslami M. 2018 About Several Numerical and Semianalytical Methods of Local Structural Analysis Int. Journal for Computational Civil and Structural Engineering 14 i 4 p. 59-69.

8. Бате К.-Ю., Вилсон Э.Л. Численные методы анализа и метод конечных элементов. М., Стройиздат, 1982.

9. Landherr J.C. Dynamic analysis of a FRP deployable box beam. Master of Applied Science Thesis. Kingston: Queen's University, 2008.

10. Lim R.A. 2016 Structural monitoring of a $10 \mathrm{~m}$ fibre reinforced polymer bridge subjected to severe damage (Kingston: Queen's University)

11. Xie A. Development of an FRP Deployable Bridge, Master of Applied Science Thesis, Department of Civil Engineering, Royal Military College of Canada, 2007.
Vladimir N. Sidorov, Corresponding Member of Russian Academy of Architecture and Construction Science, Professor, Dr.Sc, Professor of «Building Structures, Buildings and Facilities» Department, Institute of Railway Track, Construction and Structures, Russian University of Transport (MIIT), Rectorate Counselor, Professor of National Research University Moscow State University of Civil Engineering, Professor of Department «Engineering Structures and Numerical Mechanics», Perm National Research Polytechnic University; 127994, Russia, Moscow, Obraztsova st., 9, b. 9, phone: +74956814381, e-mail: sidorov.vladimir@gmail.com.

Elena S. Badina, Ph.D, Associate Professor of «Computer Aided Design» Department, Institute of Railway Track, Construction and Structures, Russian University of Transport (MIIT), 127994, Russia, Moscow, Obraztsova st., 9, b.9, phone: +74956092116, e-mail: shepitko-es@mail.ru.

Сидоров Владимир Николаевич, член-корреспондент PAACH, профессор, доктор технических наук, про- фессор кафедры «Строительные конструкции, здания и сооружения» Института пути, строительства и сооружений Российского университета транспорта (МИИТа), советник при ректорате, профессор Национального исследовательского Московского государственного строительного университета, профессор кафедры «Строительные конструкции и вычислительная механика» Пермского национального исследовательского политехнического университета; 127994, Россия, г. Москва, ул. Образцова, д.9, стр. 9, телефон: +74956814381, e-mail: sidorov.vladimir@ gmail.com.

Бадьина Елена Сергеевна, кандидат технических наук, доцент кафедры «Системы автоматизированного проектирования» Института пути, строительства и сооружений Российского университета транспорта (МИИТа), 127994, Россия, г. Москва, ул. Образцова, д.9, стр. 9, телефон: +74956092116, e-mail: shepitkoes@mail.ru. 